Int. J. Curr. Res. Med. Sci. (2017). 3(5): 100-104

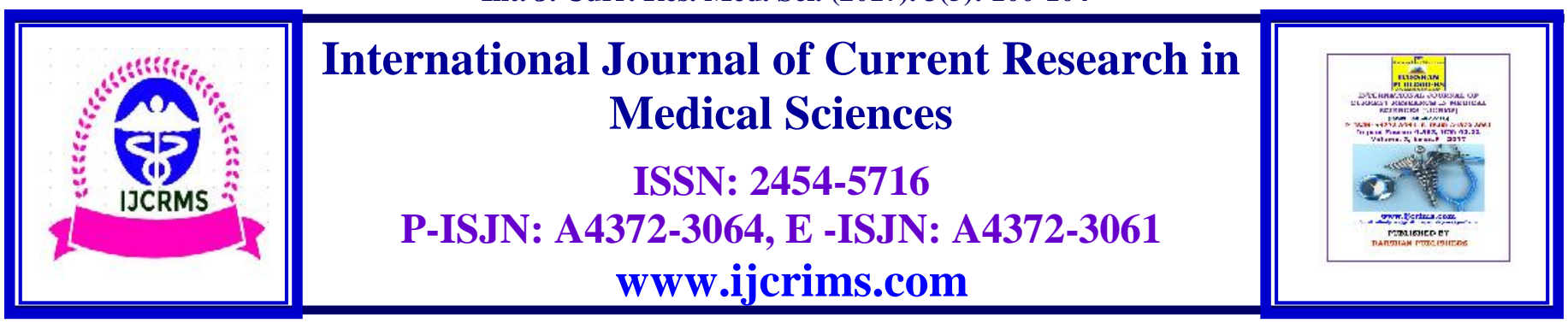

Original Research Article

Volume 3, Issue 5 -2017

DOI: http://dx.doi.org/10.22192/ijcrms.2017.03.05.014

\title{
Haematological indices of malaria patients coinfected with HIV in Umuahia
}

\section{*Obeagu,Emmanuel Ifeanyi ${ }^{1}$,Ibeh,Nancy C. $_{.}^{2}$, Nwobodo,H.A. ${ }^{3}$, Ochei,K.C. ${ }^{4}$ and Iwegbulam, C.P. ${ }^{1}$ \\ 1. Department of University Health Services, Michael Okpara University of Agriculture,Umudike,Abia State, Nigeria. \\ 2. Department of Medical Laboratory Science, Nnamdi Azikiwe University,Nnewi Campus, Anambra}

State,Nigeria.

3. Department of Medical Laboratory Science,College of Medicine, Enugu State University of Science and Technology, Enugu State, Nigeria.

4. Family Health International (FHI360) Country Office, Garki - Abuja, Nigeria

Corresponding author: Obeagu,Emmanuel Ifeanyi, Diagnostic Laboratory Unit, Department of University Health Services, Michael Okpara University of Agriculture,Umudike,Abia State, Nigeria.

emmanuelobeagu@yahoo.com,+2348037369912

\section{Abstract}

The study was done to ascertain variations in haematological indices of malaria patients living with HIV in umuahia. A total of 106 subjects were recruited for the study. 80 subjects were HIV positive patients and 26 subjects were malaria-HIV co infected patients. 60 subjects were females and 46 were males. All the subjects were selected from the two hospitals. Two different HIV screening kits were used (determine and Unigold test kits) and malaria diagnosed using stained thick films.Haemoglobin was estimated using cynmethaemoglobin method, PCV done using microhaematocrit method and thin film used for differential count. The study showed significant decrease $(\mathrm{P}<0.05)$ in platelets and packed cell volume of the HIV-malaria co infected subjects compared to persons living with HIV, significant increase $(\mathrm{P}<0.05)$ in total white blood cell and absolute lymphocytes and no significant difference $(\mathrm{P}<0.05)$ in absolute neutrophil, haemoglobin and red blood cell of HIV-malaria co infected subjects compared to HIV monoinfection and had a lesser suppression on the absolute lymphocyte. The result also showed significant decrease $(\mathrm{P}<0.05)$ in platelets, WBC, significant increase $(\mathrm{P}<0.05)$ in $\mathrm{PCV}$ and haemoglobin and no significant difference $(\mathrm{P}>0.05)$ in lymphocyte, neutrophil and red blood cell of females compared to male of the HIV-malaria co infected subjects. The study showed serious significant difference in most of the haematological parameters studied in the HIV-malaria co infected subjects.

Keywords: Haematological indices, malaria, HIV,HIV-malaria, Umuahia 


\section{Introduction}

Haematological variations are the common complications in malaria infection and they play a major role in malaria infection. These variations involve the major cell lines and the abnormalities such as anemia, thrombocytopenia and leukocytosis or leucopenia [1-3] .Haematological aberrations such as anemia, neutropenia [4], and thrombocytopenia [5] are commonly reported abnormalities associated with HIV infection. HIV has effects on the systemic inflammatory response [6].

Malaria and HIV are the two most challenging global health problems of our time, causing more than two million deaths each year and greatest medical challenges facing Africa today [7].

Both malaria and HIV can cause hematological alterations independently. Those changes include: anemia, thrombocytopenia and leucopenia have been documented as strong, independent predictors of morbidity and mortality in malaria co -infected HIV positive individuals than mono infected HIV positive individuals [8].

HIV and malaria both destroy important cells required for proper immunological and hematological functioning of the body $[9,10]$.

\section{Aim}

To ascertain level of variations in haematological indices of malaria patients co infected with HIV in Umuahia

\section{Materials and Methods}

\section{Study Area}

The study was done in the Department of University Health Services,Michael Okpara University of Agriculture,Umudike,Abia State,Nigeria and Daughters of Mary Mother of Mercy Hospital Ahieke,Umuahia,Abia State,Nigeria.

\section{Subjects}

106 subjects were recruited for the study. 80 subjects were HIV positive patients and 26 subjects were malaria-HIV co infected patients.60 subjects were females and 46 were males.

\section{Ethical consideration}

The subjects were allowed to join in the recruitment voluntarily and withdraw at any stage. Informed consents were obtained from them and confidentiality of the results assured to them.

\section{LABORATORY INVESTIGATIONS}

HIV Screening: determine and Unigold test kits were used for the detection of HIV-seropositivity following serial algorithm.

\section{Malaria Diagnosis}

Thick stained films were used to diagnose malaria.

\section{Haemoglobin estimation (Cyanmet haemoglobin method)[11]}

\section{Procedure}

With the tubes properly labeled according to the subject's number, 4ml of Drabkin solution was pipetted into the tubes, following with the addition of $0.02 \mathrm{ml}$ of well mixed venous blood, mixed and allowed to stand for 4 minutes at temperature. The absorbance was read at $540 \mathrm{~nm}$ against reagent blank. The readings were obtained from the calibration graph.

\section{Packed Cell Volume (PCV) by microhaematocrit method [11]}

\section{Procedure}

The capillary tubes were filled two-third full with well mixed EDTA anticoagulated venous blood of each subject, sealed the unfilled end, using a sealant material. The filled tubes were then placed in the microhaematocrit centrifuge and spun at $15,000 \mathrm{xg}$ for 3 minutes.The PCV was read immediately after centrifuging. 


\section{Total White Cell Count}

\section{Procedure}

Three hundred and eighty microlitre of Turk's solution was dispensed into a test rube and 20 microlitre of well mixed EDTA anti-coagulated blood was added and mixed well. The counting chamber was mounted with cover slip and allow to charge with test solution after re:: $g$ th test solution. The charged chamber was left undisturbed for 2-3 minutess for the cells to settle. The chamber was* mounted on a light microscope, the ruling were focused and the cell counted using 10 objectives. The total number of cells counted was subjected to the first principle formular.

$\mathrm{WBC}=\mathrm{N} \times 20 \times 10^{6} / 0.4$

Where $\mathrm{N}=$ number of cells counted

$20=$ dilution factor

$0.4=$ dept of the well

\section{Platelet Count}

\section{Procedure}

With the test tubes labeled accordingly. $038 \mathrm{ml}$ of filtered ammonium oxalate diluting fluid was dispensed into the tubes and $0.02 \mathrm{ml}$ of well mixed venous blood of the subjects added and allowed for 20 minutes undisturbed on blotting paper and covered with a lid. The chamber was placed on the microscope and the platelets counted.

\section{BLOOD FILM/DIFFERENTIAL WHITE CELL COUNT}

\section{Making, Fixing And Staining Blood Films}

\section{Procedure}

Thin blood films were made from well mixed EDTA anticoagulated blood,air dried and covered with Leishman stain for 2 minutes, double diluted with buffered water of PH 6.8 and allowed to stain for 10 minutes. The stain was washed with tap water. The back of the slide was wiped clean and stood in a draining rack for the smear to dry. A drop of immersion oil was placed on the lower third of the blood film and covered with a clean cover glass.

The film was examined microscopically using 10 times objective with condenser iris closed sufficiently to see the cells clearly and changed to 100X for differential count.

\section{Results}

Table 1: showing haematological indices of HIV positive subjects and malaria-HIV co infected subjects

\begin{tabular}{lccc} 
Parameters & HIV subjects & malaria-HIV subjects & Level of significance \\
\hline Platelets $\left(\mathrm{X} 10^{9} / \mathrm{L}\right)$ & $329.00 \pm 21.20$ & $292.33 \pm 15.17$ & $\mathrm{P}<0.05$ \\
WBC $\left(\mathrm{X} 10^{9} / \mathrm{L}\right)$ & $6.90 \pm 1.67$ & $8.45 \pm 2.18$ & $\mathrm{P}<0.05$ \\
Absolute & & $3.70 \pm 0.42$ & \\
Lymphocytes $\left(\mathrm{X} 10^{9} / \mathrm{L}\right)$ & $2.50 \pm 0.56$ & & $\mathrm{P}<0.05$ \\
Absolute & & & \\
Neutrophil $\left(\mathrm{X} 10^{9} / \mathrm{L}\right)$ & $4.40 \pm 1.26$ & $32.43 \pm 13.45$ & $\mathrm{P}>0.05$ \\
PCV $(\%)$ & $35.40 \pm 10.20$ & $11.28 \pm 0.92$ & $\mathrm{P}<0.05$ \\
Haemoglobin $(\mathrm{g} / \mathrm{dl})$ & $11.80 \pm 1.60$ & $3.70 \pm 0.62$ & $\mathrm{P}>0.05$ \\
RBC $\left(\mathrm{X} 10^{9} / \mathrm{L}\right)$ & $3.93 \pm 0.49$ & $\mathrm{P}>0.05$ \\
RBC=red blood cell, $\mathrm{PCV}=$ packed cell volume, WBC=Total white blood cell $\mathrm{P}<0.05=$ significant, \\
$\mathrm{P}>0.05=$ not significant & &
\end{tabular}


Int. J. Curr. Res. Med. Sci. (2017). 3(5): 100-104

\section{Table2: showing haematological indices of malaria-HIV subjects based on gender}

\begin{tabular}{lccc} 
Parameters & Male & Female & Level of significance \\
\hline Platelets $\left(\mathrm{X} 10^{9} / \mathrm{L}\right)$ & $397.50 \pm 30.16$ & $155.00 \pm 19.23$ & $\mathrm{P}<0.05$ \\
WBC $\left(\mathrm{X} 10^{9} / \mathrm{L}\right)$ & $9.95 \pm 2.18$ & $6.95 \pm 1.72$ & $\mathrm{P}<0.05$ \\
Absolute & $5.00 \pm 0.52$ & $2.55 \pm 0.68$ & \\
Lymphocytes $\left(\mathrm{X} 10^{9} / \mathrm{L}\right)$ & & & $\mathrm{P}>0.05$ \\
Absolute & $4.95 \pm 0.32$ & $4.40 \pm 0.81$ & \\
Neutrophil $\left(\mathrm{X} 10^{9} / \mathrm{L}\right)$ & $30.65 \pm 8.27$ & $33.3 \pm 15.29$ & $\mathrm{P}>0.05$ \\
PCV $(\%)$ & $10.60 \pm 0.90$ & $11.55 \pm 0.38$ & $\mathrm{P}<0.05$ \\
Haemoglobin $(\mathrm{g} / \mathrm{dl})$ & $3.53 \pm 0.17$ & $3.85 \pm 0.29$ & $\mathrm{P}<0.05$ \\
RBC $\left(\mathrm{X} 10^{9} / \mathrm{L}\right)$ & & & $\mathrm{P}>0.05$
\end{tabular}

$\mathrm{RBC}=$ red blood cell, $\mathrm{PCV}=$ packed cell volume, $\mathrm{WBC}=$ Total white blood cell $\mathrm{P}<0.05=$ significant, $\mathrm{P}>0.05=$ not significant

\section{Discussion}

The sresult showed significant decrease $(\mathrm{P}<0.05)$ in platelets and PCV of the malaria-HIV co infected subjects compared to persons living with HIV, significant increase $(\mathrm{P}<0.05)$ in $\mathrm{WBC}$ and absolute lymphocytes and no significant difference $(\mathrm{P}<0.05)$ in absolute neutrophil, haemoglobin and red blood cell of malaria-HIV co infected subjects compared to HIV monoinfection and had a lesser suppression on the absolute lymphocyte. This means that malaria may not activate immune suppression in HIV co infection.

The result also showed significant decrease $(\mathrm{P}<0.05)$ in platelets, WBC, significant increase $(\mathrm{P}<0.05)$ in $\mathrm{PCV}$ and haemoglobin and no significant difference $(\mathrm{P}>0.05)$ in lymphocyte, neutrophil and red blood cell of females compared to male of the HIV-malaria co infected subjects. The study contradicts the work of Tchinda et al. [12] which showed no significant difference $(\mathrm{P}>0.05)$ in all the haematological parameters studied by them. This could be related to geographical location and life style of the subjects.

This shows there is a significant relationship between malaria infection and thrombocytopenia. The possible causes of thrombocytopenia in malaria infection were increased sequestration and highly elevated levels of platelet bound immunoglobulin that leads to increased peripheral destruction [2]. HIV and malaria have each been reported to cause myelosuppression $[13,14]$.

\section{Conclusion}

The study showed serious significant difference in most of the haematological parameters studied in the HIV-malaria co infected subjects. Because of the high infection rate of malaria in this part of the World and its impact on the haematological parameters of HIV patients, a lot of preventive measures should be adopted to prevent its adverse effects on the haematological parameters of the HIV patients which will help to enhance their life.

\section{References}

1.Maina NR, Walsh D, Gaddy C, Hongo G, Waitumbi J, Otieno L, Jones D, Ogutu BR (2010). Impact of Plasmodium falciparum infection on hematological parameters in children living in Western Kenya. Malar J.9(3): 1-11

2.Iqbal W (2010). Hematological manifestations in malaria. Haematol Updat. 2010:35-7.

3.Mckenzie FE, Prudhomme WA, Magill AJ, Forney JR, Permpanich B, Lucas C, GasserJr RA, Wondsrichanalai C (2005). White blood cell counts and malaria. J Infect Dis.192 (2):323-30. 
4. Kuritzkes DR (2000). Neutropenia, neutrophil dysfunction, and bacterial infection in patients with human immunodeficiency virus disease: the role of granulocyte colony-stimulating factor. Clin Infect Dis. 30(2):256-60

5.Sullivan PS, Hanson DL, Chu SY, Jones JL, Ciesielski CA (1996).Surveillance for Thrombocytopenia in Persons Infected With HIV: Results From the Multistate Adult and Adolescent Spectrum of Disease Project. J Acquir Immune Defic Syndr. 14(4):374-9.

6.Hochman S, Kim K (2009). The impact of HIV and malaria co-infection: what is known and suggested venues for further study. Interdiscip Perspect Infect Dis. 2009:1-8.

7.World Health Organization (2015).Malaria in HIV/AIDS patients. http://www.who. int/malaria/areas/high_risk_groups/hiv_aids_p atients/en/.

8.Grimwade K, French N, Mbatha DD, Zungu DD, Dedicoat M, Gilks CF (2004). HIV infection as a cofactor for severe falciparum malaria in adults living in a region of unstable malaria transmission in South Africa. AIDS.18 (3):547-54.

9.Tagoe DNA, Boachie J (2012).Assessment of the impact of malaria on cd4+ $\mathrm{T}$ Cells and haemoglobin levels of HIV-malaria co-infected patients. J Infect Dev Ctries. 6: 660-663. https://doi.org/10.3855/jidc.

10.Chavale H, Santos-Oliveira JR, Da-Cruz AM, Enosse S (2012). Enhanced T cell activation in Plasmodium falciparum malaria-infected human immunodeficiency virus-1 patients from Mozambique. Mem Inst Oswaldo Cruz. 107: 985-992.

11.Cheesbrough M (2006). District Laboratory Practice in Tropical Countries (Part 11, $2^{\text {nd }}$ ed).

12.Tchinda GG, Atashili J, Achidi EA, Kamga HL, Njunda AL, Ndumbe PM (2012).Impact of Malaria on Hematological Parameters in People Living with HIV/AIDS Attending the Laquintinie Hospital in Douala, Cameroon.Plos On.7(7): e40553.

13.Bashawri LA, Mandil AA, Bahnassy AA, Ahmed MA (2002) Malaria:hematological aspects. Ann Saudi Med. 22(5-6): 372-6.

14.Suresh V, Satya A, Singh V P, Madhukar R, Vivekananda VD (2008). Hematological profile of HIV patients in relation to immune status - A hospitalbased cohort from Varanasi, North India. Turk J Hematol 25: 13-19.

\begin{tabular}{|c|l|}
\hline \multicolumn{2}{|c|}{ Access this Article in Online } \\
\hline Q & Website: \\
& www.ijcrims.com \\
\cline { 1 - 1 } Quick Response Code & Subject: \\
\hline
\end{tabular}

How to cite this article:

Obeagu,Emmanuel Ifeanyi, Ibeh,Nancy C., Nwobodo,H.A.,Ochei,K.C. and Iwegbulam, C.P. (2017). Haematological indices of malaria patients coinfected with HIV in Umuahia. Int. J. Curr. Res. Med. Sci. 3(5): 100-104.

DOI: http://dx.doi.org/10.22192/ijcrms.2017.03.05.014 